\title{
EXPLORING THE BRAND BUILDING PROCESS IN MICRO VENTURES THROUGH SOCIAL MEDIA USAGE: A STUDY OF THE WOMEN-OWNED HOME-BASED COOKED FOOD DELIVERY SERVICES IN KHULNA CITY IN BANGLADESH
}

\author{
Farzana Akther ${ }^{1 i}$, \\ Sk. Md. Reazul Kabir'2, \\ Mst. Naznin Sultana ${ }^{2}$, \\ Imtiaz Masroor ${ }^{3}$ \\ ${ }^{1}$ Assistant Professor, \\ Department of Business Administration, \\ North Western University, \\ Khulna 9100, Bangladesh \\ ${ }^{2}$ MBA Program, \\ Business Administration Discipline, \\ Khulna University, \\ Khulna 9208, Bangladesh \\ ${ }^{3}$ Lecturer, \\ Department of Business Administration, \\ North Western University, \\ Khulna 9100, Bangladesh
}

\begin{abstract}
:
Investigation on the practice of social media in order to build a brand in the digital era is the purpose of this study. Identification of the impact of the usage and functionalities of social media on building a brand is the goal of this endeavour. The research explores the impact of different communication mode in brand management. The association of brand development and firm-created interaction and user-generated interaction has also been exploited. A qualitative study has been conducted for the research. Data are collected from semi-structured interviews with 8 shops owners of the online homemade food industry in Khulna city who have a strong command of social media. They practice social media for their business. They provide initial information of actions taken by firms and their enthusiasm behind engaging this industry. The outcome obtained from this effort displays the firm's engagement of strengthening awareness and image of a brand by utilizing social media interaction initiated by firms and solidification of trust and loyalty of a brand by exploiting actions taken in social media by the users. Social media's capacity to build the equity for a brand in a new yet convincing industry is explored in this exertion.
\end{abstract}

${ }^{i}$ Correspondence: email fa.nwu.bd@gmail.com 
Farzana Akther, Sk. Md. Reazul Kabir, Mst. Naznin Sultana, Imtiaz Masroor

EXPLORING THE BRAND BUILDING PROCESS IN MICRO VENTURES THROUGH

SOCIAL MEDIA USAGE: A STUDY OF THE WOMEN-OWNED HOME-BASED COOKED

FOOD DELIVERY SERVICES IN KHULNA CITY IN BANGLADESH

JEL: L60; L96; M10

Keywords: social media communication, firm created social media communication; user created social media communication, brand image, brand trust, brand awareness

\section{Introduction}

The increasing usage of social media has developed a complete innovative genre for brands and related companies which has forced them to search for new collaborative ways to reach and engage user groups (Gallaugher \& Ransbotham, 2010). This marketing channel is able to provide unparalleled scope for building status and brand and this channel is growing rapidly which has already reached more than two-thirds of entire Internet users (Correa et al., 2010). In our society, there is a rapid dissemination of social media (Dickey et al., 2010) which is encouraging the usage of social media by the firms for brand development and marketing activities (Gallaugher \& Ransbotham, 2010), though all the information available on social media are not authentic (Shearer \& Mitchell, 2021) and there are a good number of businesspeople who are not accustomed to this new accommodation (Kaplan \& Haenlein, 2010). Nonetheless, a better archive and a better medium of communication are provided by social media (Thackeray et al., 2008) and social media plays a mediating role in the achievement of outstanding firm performance through innovative ways of marketing activities to connect customers to the brand (Tajvidi \& Karami, 2021). Both sellers and buyers get the opportunity of sharing their perspectives on social media platforms (Castillo et al., 2021).

Contemporary usage of social media platforms for sharing knowledge binds the professionals to rethink their approaches towards consumers and consumers prefer informal communication on these platforms (Kwayu et al., 2021). Transferring consumers voice patterns from dialogue to trialogue vehicles communicating between one another and with the authority of the firm for the betterment of the firm (Lipsman et al., 2012; Mangold \& Faulds, 2009). The organization has the scope to develop impactful customer relationships by using social media (Gashi \& Ahmeti, 2021). This customer category includes both existing and potential customers who can interactively join together to identify the problem and identify solutions. For the sake of the relationship, this interactive pact can interchange the traditional roles of customer and seller. Indeed, value-generating customer attachment orientation can be introduced through content that generates communication and peer-to-peer communications can influence the buying decisions of a customer (Sashi, 2012). New opportunities for brand interactions have been generated at the dawn of different platforms of social communication. This is supported by the evidence of internet-based brand engagement activity on social media. eWOM (e-word of mouth) is a tremendous way of expanding brand awareness and spreading brand intention among consumers (Bilal et al., 2021). By using social media, it can be affordable for a marketer to relate with attainable and probable consumers by gathering information from two-way communication which also increases reach through 
Farzana Akther, Sk. Md. Reazul Kabir, Mst. Naznin Sultana, Imtiaz Masroor

EXPLORING THE BRAND BUILDING PROCESS IN MICRO VENTURES THROUGH

SOCIAL MEDIA USAGE: A STUDY OF THE WOMEN-OWNED HOME-BASED COOKED

FOOD DELIVERY SERVICES IN KHULNA CITY IN BANGLADESH

consumers in an unmediated and quick manner. Additionally, networking based on social media, brand recommendations, and information allocation is important to marketers. When people hear about a product or service from a friend on Facebook, they're 15 percent more likely to buy it than when they learn about it any other way, according to the social network's statistics (Childers \& Boatwright, 2021). Aside from that, social media platforms make it possible to distribute information about products and services in a viral or rapid fashion (Berger \& Milkman, 2012). The effect of this is that corporations are actively participating in new social media marketing techniques and approaches (Lashgariet al., 2018). The importance of source dependability is shown in a more in-depth examination of communications in social media, accomplished by separating social media communication created by firms from social media communication generated by users. The firm generated contents have a positive impact on consumers while they make a decision and helps the brand to achieve a distinct position in the mind of customers (Raji et al., 2020). Digital platforms are taking over the place of traditional media and getting popular among customers and customers are generating communications and concepts for social media (Burgess \& Banks, 2010). Consumers are able to tell the difference between user-generated and firm-created social media content because of the differing impacts on brand image dimensions. Social media contents created by the firms have a good effect on brand awareness and image, whereas social media communication generated by the users has a positive effect on brand trust and loyalty.

Social media platforms are now being used by a whole lot of people as a platform for sharing information (Chen \& Zhu, 2021). There has been a dramatic shift in the information sharing environment as a result of the rise of social media. People of different paradigms have increased the use of social media in different phases of their lives (Gaini et al., 2021). Consumers' communication patterns are being influenced by the rising relevance of programs such as Facebook, YouTube, and others in their daily routines. More time is being paid by the people on social media, and as a result, more and more conversation is taking place there. Through interactive strategy development, there is always a scope for social media marketing to enable brand loyalty through which brand engagement for the consumers (Hazzam, 2021). Khulna's home-cooked food industry is gaining in popularity by the day. The majority of store owners practice social media to operate their trades. And each one of them is working hard to build their own brand. The dynamic, omnipresent, and often real-time contact made possible by social media significantly alters the landscape for brand managers. The firm's actors must have a thorough grasp of this transformation.

In this study, efforts are put to generate an investigation towards the development of a brand using social media. It is also emphasized to find the impact of the firm created social media communication towards the expansion of a brand image and awareness. Investigative efforts have also been given to identifying the impact of user-generated social media communication on the creation of the brand trust. 
Farzana Akther, Sk. Md. Reazul Kabir, Mst. Naznin Sultana, Imtiaz Masroor

EXPLORING THE BRAND BUILDING PROCESS IN MICRO VENTURES THROUGH

SOCIAL MEDIA USAGE: A STUDY OF THE WOMEN-OWNED HOME-BASED COOKED

FOOD DELIVERY SERVICES IN KHULNA CITY IN BANGLADESH

\section{Literature Review}

\subsection{Brand Image}

In other words, a company's image may be well-defined as the representation of a brand in the minds of consumers as the outcome of brand association (Keller, 1993). Additionally, consumers' perceptions of and attitudes toward a brand shape its image (Roy \& Banerjee, 2007). To paraphrase Aaker (1991), "brand image" is a collection of consumer-recognized activities. There is a strong correlation between the uniqueness of the brand image of a product and its distinctiveness according to Bearden and Etzel (1982) and Park and Srinivasan (1994). It has been shown that brands with a strong brand image outperform their competitors in terms of consumer perceptions (Hsieh \& Li, 2008). Because of this, customers' actions will be influenced and influenced by the brand image (Burmann et al., 2008). Products with strong brand images may be seen as having higher quality and value by customers, who base their opinions on such views to some extent (Richardson et al., 1994). Consumers' perceptions of quality and value are severely harmed by brand image, bestowing to learning directed by Jacoby et al. (1971).

\subsection{Brand Awareness}

When the point derives to building brand equity, brand consciousness might be a vital and important component that is often overlooked (Aaker, 1996); (Cobb-Walgren et al., 1998). To put it another way, Aaker defined brand awareness as the buyer's recollection of the structure of the brand. It is through constant exposure, increased familiarity, and strong linkages with the product and with the experience that brand awareness is built (Keller, 1998). Consumers' higher cognitive processes may be affected by strong brand connection, according to Keller (1993 \& 1998). Brand awareness and brand association, according to Pitta and Katsanis (1995), are intertwined with brand awareness developing in the subconscious of the client before the brand connection is formed and ingrained in the customer's reminiscence. Saini and Chauhan (2017) noted that brand awareness and brand association are linked.

\subsection{Brand Association}

A set of entire brand name associations helps a brand to build up a clear brand identity, whereas some consumers could connect better consequences to useful advantages; emotional pricing helps the brand top of others. Building brand association, a firm needs to evaluate its brand as well competitors' brand through consumer orientation (Aaker, 2000). When the purchaser is choosing among different products or services, the association plays a vital role in finalizing this; therefore, the brand association is a very essential determinant of brand equity. Hence, the brand association can be looked at or associated with the image, preference and liking of the brand (Keller, 1993), its trustworthiness and whether it delivers its pledge and its reliability (Piaralal \& Mei, 2015). According to Aaker (1991), product associations and organizational affiliations are 
Farzana Akther, Sk. Md. Reazul Kabir, Mst. Naznin Sultana, Imtiaz Masroor

EXPLORING THE BRAND BUILDING PROCESS IN MICRO VENTURES THROUGH

SOCIAL MEDIA USAGE: A STUDY OF THE WOMEN-OWNED HOME-BASED COOKED

FOOD DELIVERY SERVICES IN KHULNA CITY IN BANGLADESH

the two most often cited types. Brand loyalty is built on the basis of associations, which also provide value to both the company and its consumers.

\subsection{Brand Trust}

Scholars have defined the notion of brand trust in diversified ways. The confidence a customer builds in the brand's trustworthiness and integrity is one way to describe "Brand Trust". Adding to that, consumers' perceptions of danger are taken into account when determining brand trust (Delgado-Ballester, 2004). When it comes to long-term, high-relationship clients, this strategy is seen as a thoughtful one (Chaudhuri \& Holbrook, 2001). A variety of studies have shown that consumers' confidence in a brand may grow as a result of many distinct reasons. A consumer's total happiness with the product is the only factor that contributes to brand trust referring to Delgado-Ballester and Munera-Aleman (2005). Consumers' faith in brands is bolstered by attributes for example brand likelihood, brand competency, and brand repute (Lau \& Lee, 1999). The idea of building customer confidence in a brand by engaging in corporate citizenship and social responsibility has also been floated (Willmott, 2003). It has been stated that building brand loyalty requires more than just building confidence in a business; it also necessitates having a positive brand effect (Ringberg \& Gupta, 2003). Brand trust is considered to be the most crucial factor in building a connection between consumers and brands, according to many experts in marketing and advertising (Portal et al., 2019). According to Blackston (1992), belief is an important part of a consumer-brand connection.

\subsection{Brand Loyalty}

On-line marketing literature and social media have both focused extensively on the need of customer loyalty (Hawkins \& Vel, 2013). In this context, loyalty in online environments has been defined as a customer's positive attitude toward a product/website/brand and their habit of making repeat purchases (Anderson \& Srinivasan,2003). Similarly, the emotional reaction and sentiments toward the activity or product have been previously studied on brand loyalty intentions (Ajzen, 1991). Leckie et al. (2016) has proposed that continuous brand loyalty with a service supplier is explained by a positive consumers angle. Brand loyalty suggests that the extent of the commitment of a client to his brand and the way persistently he repeats his purchase for the identical brand. A loyal client can like better to purchase his brand systematically.

\subsection{Use of Social Media as Brand Communication}

Using the newest interactive technology, people's lifestyles plus businesses are changing rapidly. In recent years, organizations have realized the value of the internet and have made steps to ensure that they are engaged in internet-based communities (Berthon et al., 2012). Netizens have been given unprecedented access to online exposure because of the rise of Internet 2.0 technologies, particularly social media (Chen, 2012). Companies and their consumers may now interact in new ways thanks to social media platforms. A 
Farzana Akther, Sk. Md. Reazul Kabir, Mst. Naznin Sultana, Imtiaz Masroor

EXPLORING THE BRAND BUILDING PROCESS IN MICRO VENTURES THROUGH

SOCIAL MEDIA USAGE: A STUDY OF THE WOMEN-OWNED HOME-BASED COOKED

FOOD DELIVERY SERVICES IN KHULNA CITY IN BANGLADESH

company's ultimate goal is to connect with and learn from its target audience in order to shape the perceptions of the people who buy its products (Brodie et al., 2013). As a mass phenomenon, social media has broad appeal across a wide range of demographics (Kaplan \& Haenlein, 2010). Brands and products are often mentioned in the material made by internet users, which helps to raise brand awareness (Berthon et al., 2008). Users are increasingly turning to social media as an alternative to traditional forms of advertising, according to research (Karakaya \& Barnes, 2010).

\subsubsection{Firm-created Social Media Communication}

Buyers now believe social communication platform content to be more trustworthy over old-style marketing communications channels (Karakaya \& Barnes, 2010; Swain \& Cao, 2014). As a result, social media may be recognized as an essential part of any kind of marketing and brand activity (Hutter et al., 2013). For brands, the social media's elasticity enables them to develop manuscript in a variety of formats and distribute it across several social networks. Firm-created communication is the term for this process. To put it another way, it's the direct sharing of any kind of content made by companies on their official social media accounts (Daiya \& Roy, 2016; Laroche et al., 2013). People use it to sell items on online platforms with the intention of increasing brand awareness (Akar \& Topçu, 2011). Create a network of communication with the brand to a developing market, as well as offer themes for discussion that may foster connections between the company and its new customers and between the customers (Gensler et al., 2013). As a widespread phenomenon with the broad demographic appeal, corporate social media communications have been acknowledged (Kaplan \& Haenlein, 2010). Advertisers' usage of social media generated by their own companies is on the rise, but it's still a relatively new trend (Nielsen, 2013). An agency's reputation may be characterized by utilizing the viral transmission of information through the Internet (Li \& Bernoff, 2011), as well as the better possibility for reaching a wider audience than traditional media (Li \& Bernoff, 2011).

\subsubsection{User-generated Social Media Communication}

If you're looking for a unique way to analyse your brand, social media is it. One can achieve an extraordinary level of consumer participation in brand-related activities via social media. As a result, it could be appropriate to mention that in this platform the content is predominantly consumer-created (Andéhn et al., 2014). Creating and sharing are liked by people. Scholars interpret this as user-generated content when this kind of thing occur on the internet-based platform which contains different essentials like blogs, forums, videos, and pictures (Korkofingas \& Ang, 2010).

\subsection{Word-of-Mouth (WoM) and eWoM}

Social media associates with eWOM with the online customer to customer interaction concerning brands (Munting et al., 2011). eWom, according to research, is having greater credibility, affinity plus connection for the purchaser than a marketer-created source of 
Farzana Akther, Sk. Md. Reazul Kabir, Mst. Naznin Sultana, Imtiaz Masroor

EXPLORING THE BRAND BUILDING PROCESS IN MICRO VENTURES THROUGH

SOCIAL MEDIA USAGE: A STUDY OF THE WOMEN-OWNED HOME-BASED COOKED

FOOD DELIVERY SERVICES IN KHULNA CITY IN BANGLADESH

knowledge on online (Gruen et al., 2006). Now a day's social media become an ideal tool for eWom, as a result, user generate and unfold brand-related info to their relatives, peers, friends (Kim \& Ko, 2012). Some studies examine the WoM activity related to brands on Twitter. Consumer postings establish an information diffusion process that includes stigmatization remarks, feelings, and opinions from the public, they understand.

\section{Material and Methods}

\subsection{Research Approach}

This study has been used through the exploratory method. Exploratory research seeks to investigate areas that are not researched sufficiently and "Explanatory designs seek to establish cause-and-effect relationships. Their initial purpose is to determine how events occur and which ones may influence explicit outcomes" (Houghton, 2015).

The information has been collected in the form of primary research. Face to face personal interviews were conducted to collect the data from the online homemade food shop owner. The result of the interview has been transmitted into a script. Where all the questions have been asked through what, why and how.

\subsection{Measurement of Constructs}

In chapter 2, the literature review has been demonstrated and from that, the parameters of the investigation have been extracted. According to the parameters of the investigation, an interview guide has been prepared and interviews with the owner of the homemade food shop of Khulna have been conducted.

Afterwards, a transcript of this interview has been written. To analyse the factors, the entire transcript has been grouped so that we can get the findings. After that, the finding has been compared with the parameters. The importance of grouping is that it shows the relation between the characteristics of the parameters in terms of the present scenario of the online homemade food industry Khulna.

\subsection{Data Analysis Process}

The data analysis process began with reviewing the literature. From those literature parameters of investigations were extracted. According to that interview, a guide was prepared. With that semi-structured interview, a guide interview has been conducted. From those interviews, the interview transcript was written. Then the transcript was grouped to analyse the preliminary findings of the study. Then the transcripts were compared with preidentified parameters of investigations. And at the end, the research theme was defined.

\subsection{Challenges in Data Management}

All the data collected has been via face-to-face personal interviews. From this data, the transcript has been produced. Each interviewee has faced different challenges. This has been a challenge in managing and analysing the data. These challenges have been treated 
Farzana Akther, Sk. Md. Reazul Kabir, Mst. Naznin Sultana, Imtiaz Masroor EXPLORING THE BRAND BUILDING PROCESS IN MICRO VENTURES THROUGH SOCIAL MEDIA USAGE: A STUDY OF THE WOMEN-OWNED HOME-BASED COOKED FOOD DELIVERY SERVICES IN KHULNA CITY IN BANGLADESH

by using the meaning of analysis context as a unit of analysis. This means that the data will be coded for its meaning, not sentence by sentence.

\subsection{Population and Sample}

For the case study, 8 online homemade food shops have been chosen.

Table 1: Description of the in-depth interviews made

\begin{tabular}{|c|l|c|c|}
\hline$\#$ & Organization & Respondent's Status & Duration \\
\hline 1 & Humaira's Pastry & Owner & $35 \mathrm{~min}$ \\
\hline 2 & Cake n Bake & Owner & $19 \mathrm{~min}$ \\
\hline 3 & Bou Matar Ranna Banna & Co-owner & $25 \mathrm{~min}$ \\
\hline 4 & Lucy's cookbook & Owner & $20 \mathrm{~min}$ \\
\hline 5 & Tasty Pastry & Co-owner & $22 \mathrm{~min}$ \\
\hline 6 & Pride Tiffin Box & Co-owner & $20 \mathrm{~min}$ \\
\hline 7 & AJ's Kitchen & Co-owner & $21 \mathrm{~min}$ \\
\hline 8 & Cook Studio & Owner & $19 \mathrm{~min}$ \\
\hline
\end{tabular}

Source: Field Survey (2021).

To conduct a satisfactory and organized interview process, the following activities has been realized: firstly, contact the prospect interviewees over the phone to set an interview date and location to conduct the interview, secondly, manage the interview using the prepared Interview Guide. Thirdly, the duration of the face-to-face interviews differed upon each case and finally, the entire interview has been audio recorded.

\section{Results and Discussion}

In this chapter, the focus is on the results of the field research and its analysis. First, each parameter of utilization of social media for developing the brand according to the transcript of the interviewed company is defined. Then the data of all companies in the parameter is displayed and after that, each parameter with the scenario of the field data is discussed.

\subsection{Findings}

\subsubsection{Customer Communication Mode}

This figure shows the customer communication mode of the firm. It describes how firms communicate. 


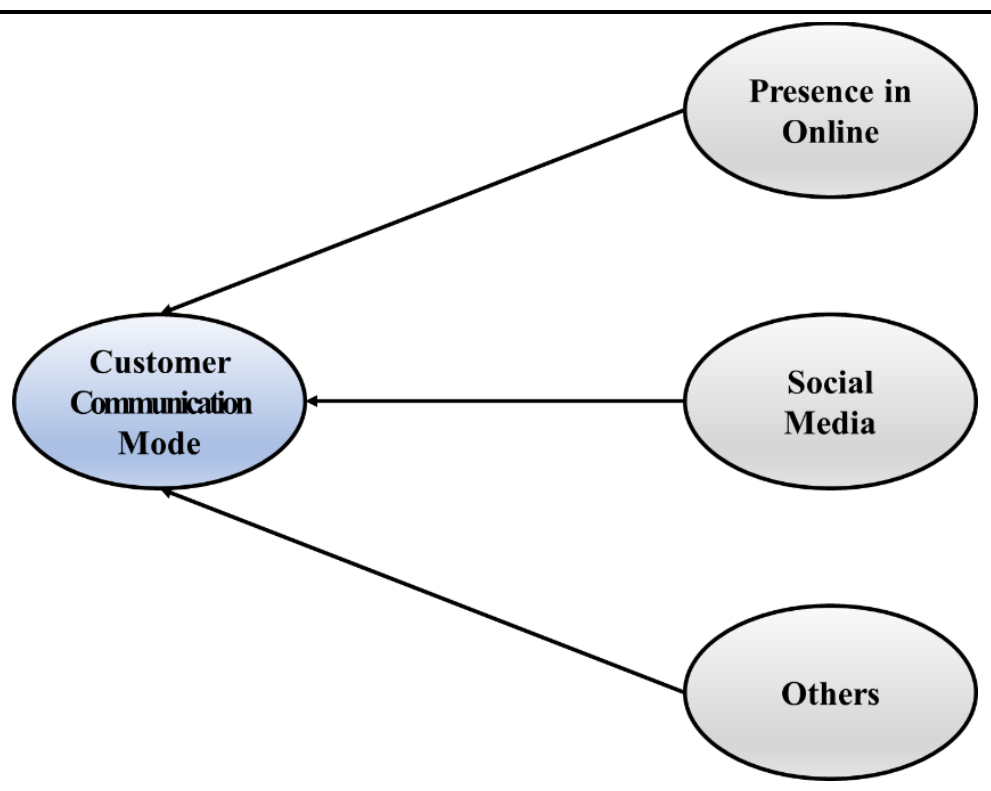

Figure 1: Customer communication mode

The homemade food industry of Khulna is mostly run online. The shop owners use different media to communicate but that is less important in this industry. They exist online through social media. They don't have any website. They use a business card and leaflet. Pride Tiffin Box has its own field officer to communicate with the customer. Besides Cook Studio and Pride Tiffin Box, all others shops attend different fairs.

\subsubsection{Social Media Communication Channel}

The figure shows the social media platform used by the firms.

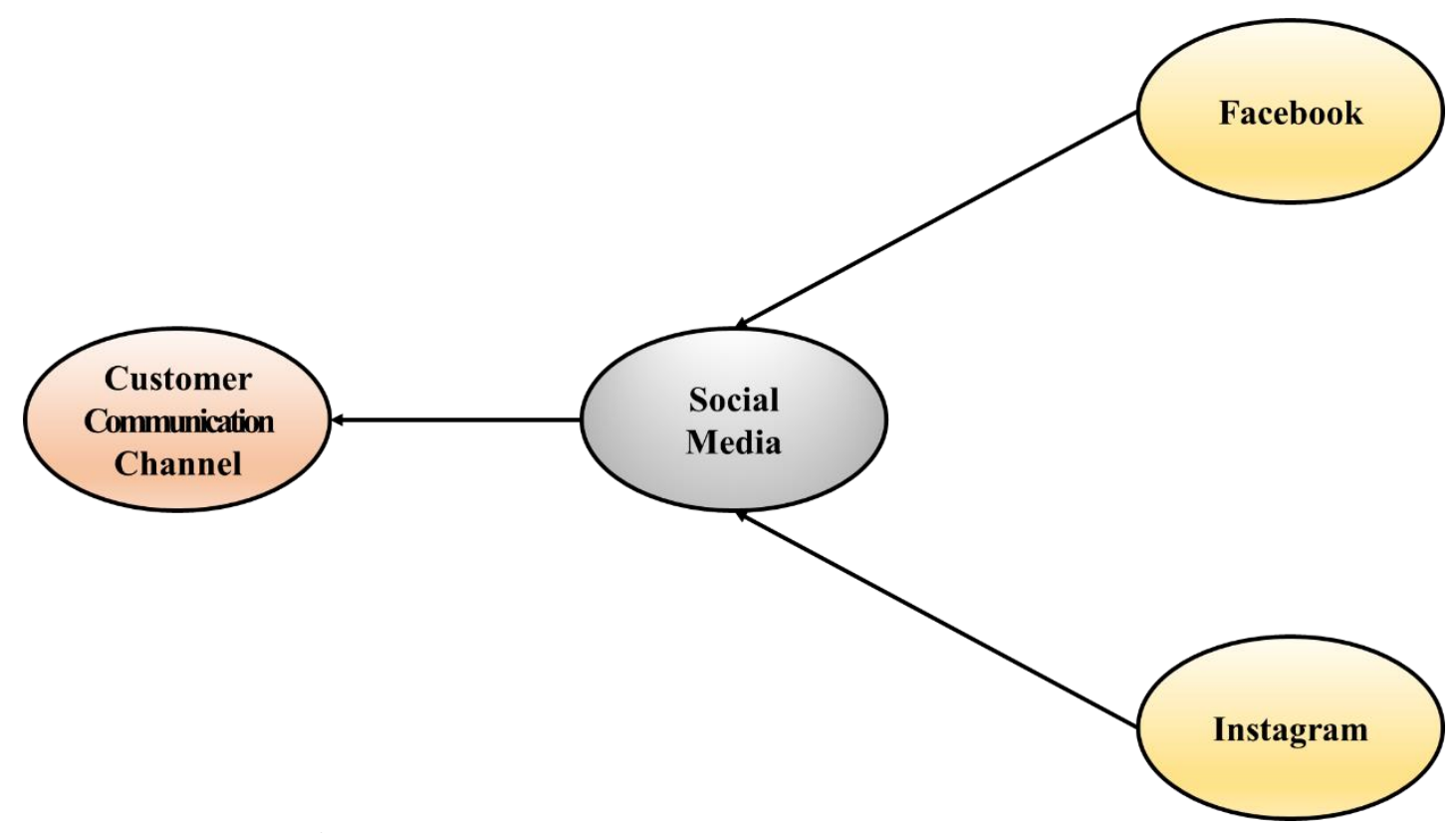

Figure 2: Social media communication identification 
While conducting the survey it is found that all shops communicate through Facebook. Tasty Pastry has an Instagram account. All the shops emphasis on Facebook. From the survey, it is clear that the whole industry is dependent on Facebook for communication. Other alternative doesn't play any crucial role in this business.

\subsubsection{Firm-created Social Media Communication}

\subsubsection{Communication Framework and Data Dissemination}

The figure is for showing the element of communication and data dissemination channels. The figure shows how the firm delivers the message.

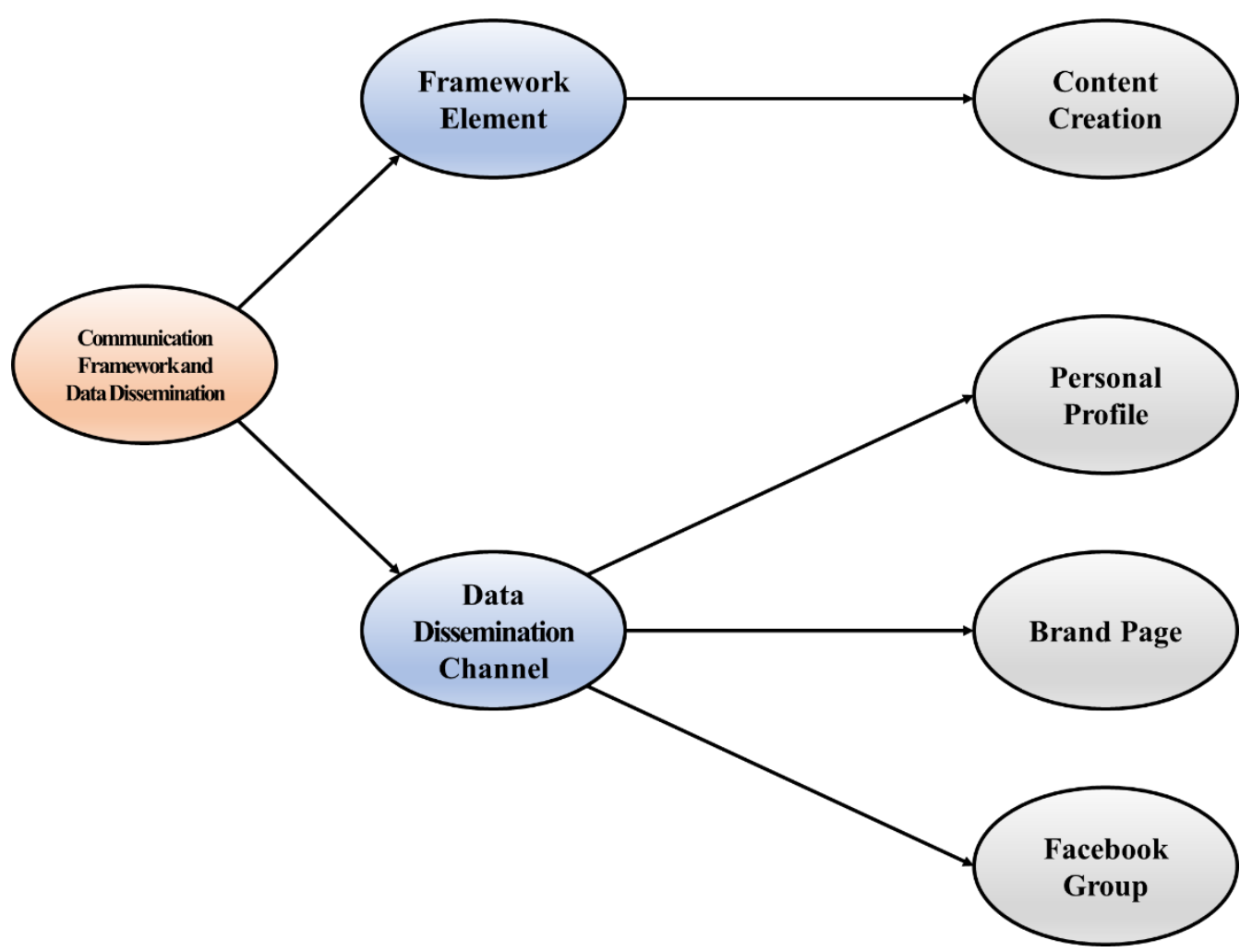

Figure 3: Element of communication and data dissemination channel

In the survey, it is found that the communication framework is the creation of content. Shops created communication content to deliver the message. And it also found that shops use more or less three channels to provide information through social media. Later on, discussion part, we will discuss the matter briefly.

\subsubsection{Social Media Content and Post Frequencies}

This figure shows the post frequencies and content elements. 


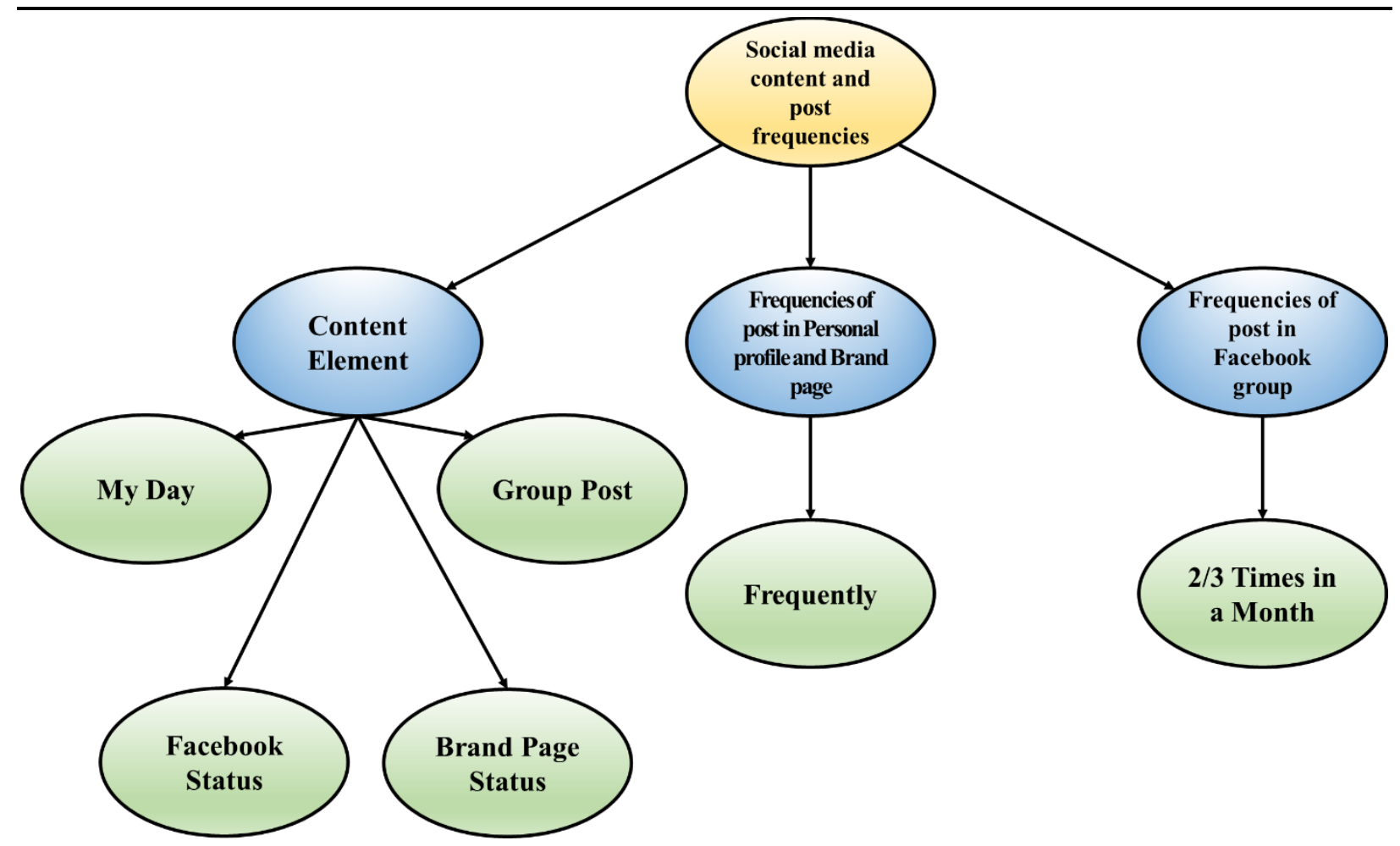

Figure 4: Post frequencies and content element

During the survey, it is found that companies use different functions of Facebook to create and provide content. Shops use their Online Brand Shop Page. Post on different foodies' groups, their personal profiles. Humaira's Pastry's owner posts a picture on her My Day option of her personal profile. Shop owners post regularly on their personal page and brand page. 2/3 times in a month they post foodies group of Khulna city. All shop owners think that this foodie group helps them a lot in this business.

\subsubsection{Communication Approach and Product \& Message Characteristic}

This figure shows the approach of communication, degree of digitalization and the message context. 


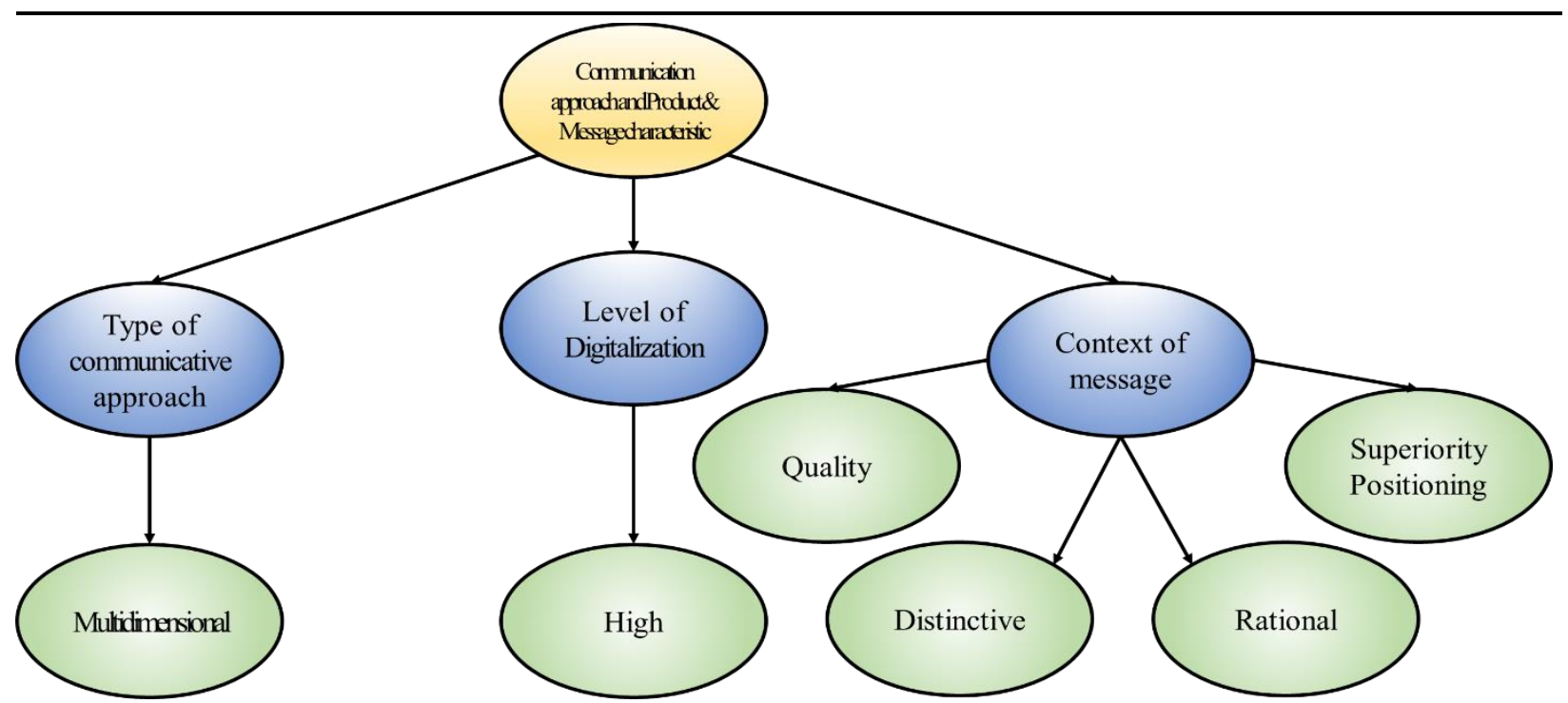

Figure 5: Approach of communication, degree of digitalization and the message context

All companies use composite ways of social media communication. They try to use as much function they can use. They try to use them collectively to pursue the consumer. They promote their product on the digital platform. Digitalization can also help the shop owner to offer valuable information about the firm's product to people, enabling visibility and awareness by a larger number of customers relatively at a low cost. In the survey, it has been found that most of the shops design their message to convey quality and rapport. Humaira's Pastry and Lucy's Cook Book also focus on distinctiveness. Cake $\mathrm{n}$ Bake and Tasty pastry try to promote superiority in product and service through message content. Pride Tiffin Box's message tries to give customers a feeling that they provide good food at a low cost.

\subsubsection{Brand Association Using Social Media}

This figure is for brand equity and association.

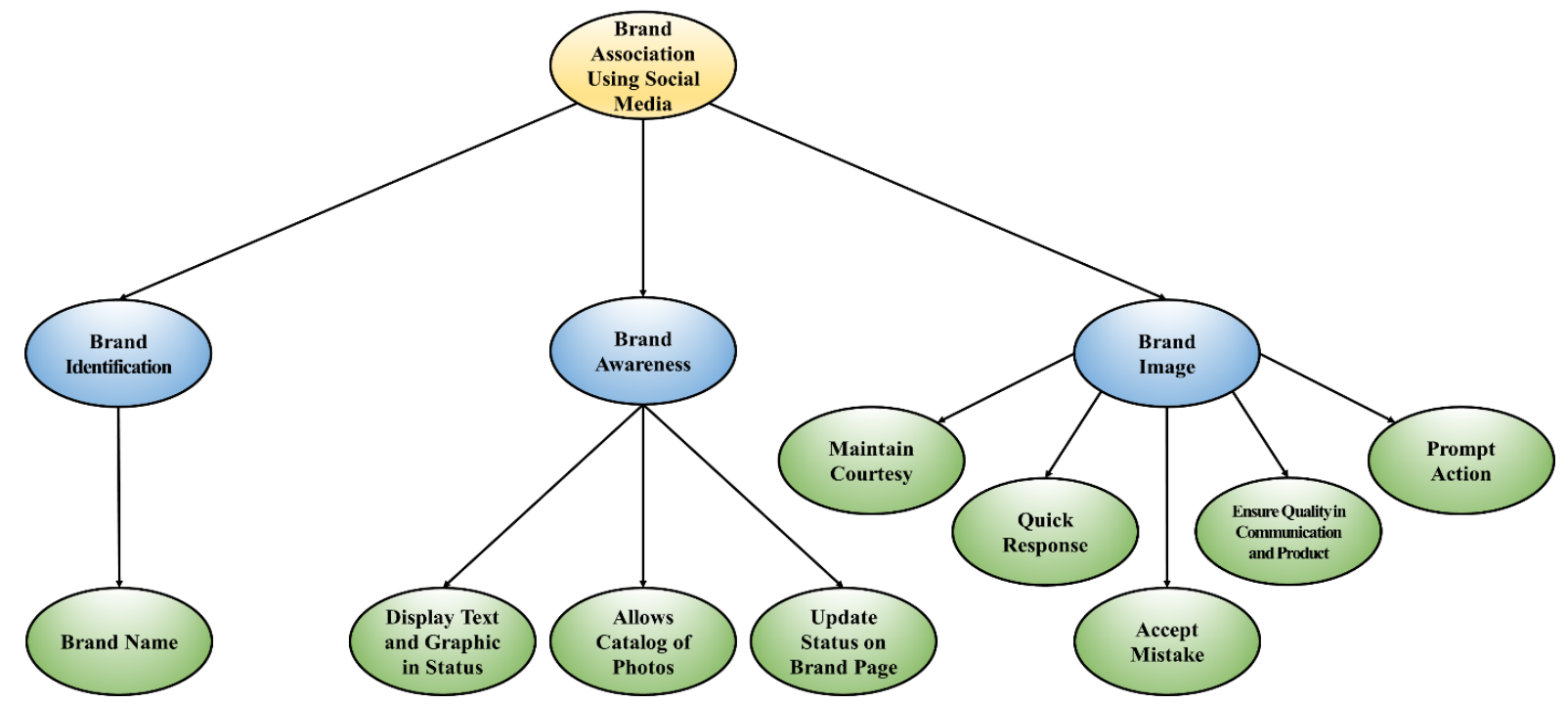

Figure 6: Brand equity and association 
Farzana Akther, Sk. Md. Reazul Kabir, Mst. Naznin Sultana, Imtiaz Masroor

EXPLORING THE BRAND BUILDING PROCESS IN MICRO VENTURES THROUGH

SOCIAL MEDIA USAGE: A STUDY OF THE WOMEN-OWNED HOME-BASED COOKED

FOOD DELIVERY SERVICES IN KHULNA CITY IN BANGLADESH

In survey it is cleared that all of the brand can be recognized by their name. They create awareness by the picture of their product, their status on Facebook. During the survey, most of the shop owners agreed that courtesy and well behavior is important in making a positive brand image. The quick response also plays a vital role. Pride tiffin box accepts their mistakes. All shops agreed that quality is most important. If anyone compromise with the quality, he/she will suffer in long run. AJ's Kitchen tries to meet the requirements of the customer. They think all of these will help them to create a positive brand image. They also agree that it is tough online. So, they try to communicate and provide information as early as possible through their social media page.

\subsubsection{User-generated Social Media Communication}

The figure shows the content and community belonging and describes how eWoM and the referral system works.

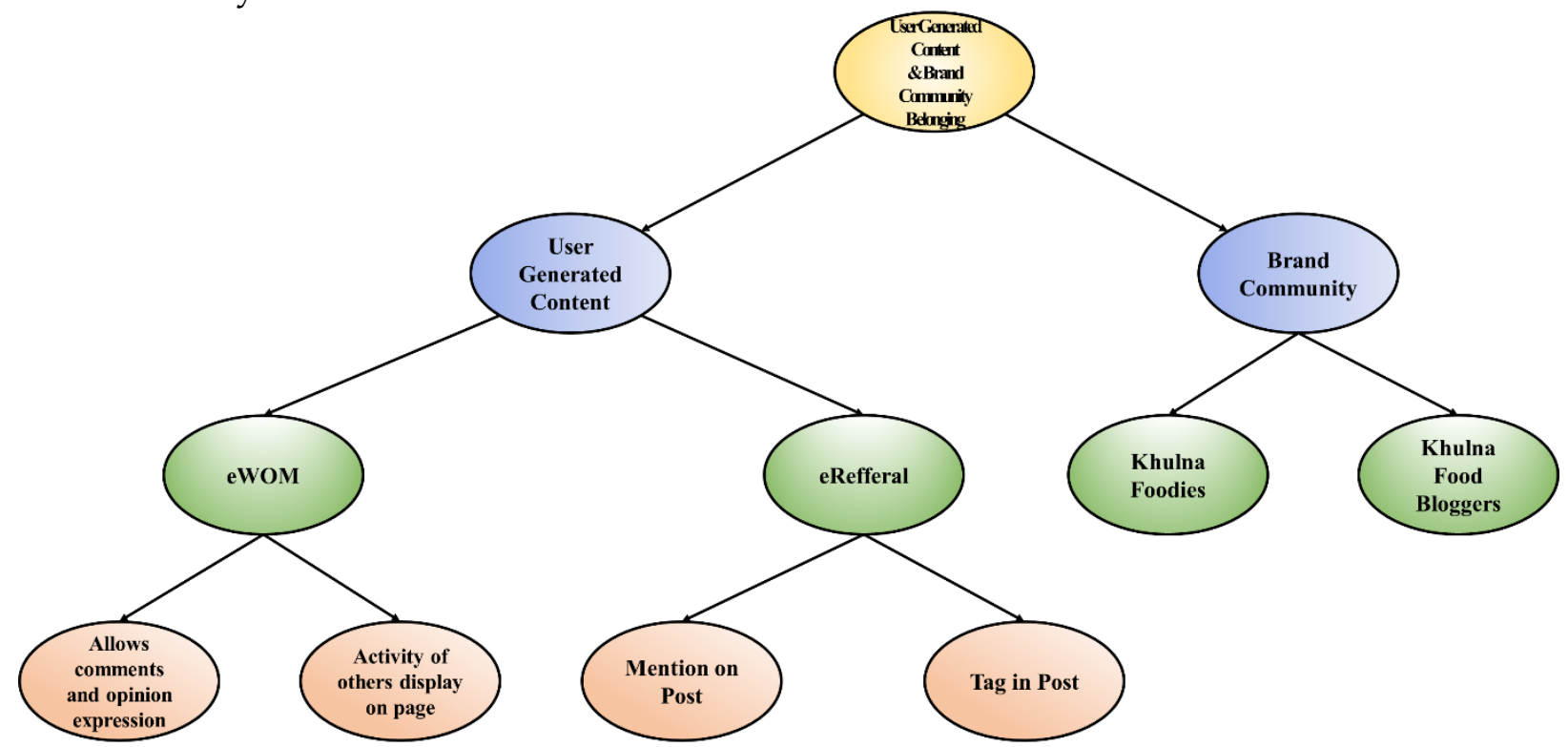

Figure 7: Content and community belonging and WoM element and eReferral process

Consumer's trust in an Internet vendor is an issue commanding ever more attention. During conducting a survey, it has been clear that the trust of the customer basically depends on user-generated content. People post a review of the product and share their opinion with their friends and family. If they heard a positive review of the product, they easily buy the product. All the shop owners agreed that this online homemade food industry is basically based on review and referral. Foodies' groups play a key role in this regard. When companies post their promotional posts, people make comments on the post. There are two foodies' groups that are very popular- Khulna foodies and Khulna food bloggers. Consumer shares their experiences. So, others people are come to know about the product. Humaira's pastry, Tasty pastry and cook studio also post on different girls Facebook groups of Khulna.

eWOM helps a lot in the homemade food industry Khulna. When company post their advertisements on a brand page people like and comment on the post. They share 
Farzana Akther, Sk. Md. Reazul Kabir, Mst. Naznin Sultana, Imtiaz Masroor EXPLORING THE BRAND BUILDING PROCESS IN MICRO VENTURES THROUGH SOCIAL MEDIA USAGE: A STUDY OF THE WOMEN-OWNED HOME-BASED COOKED FOOD DELIVERY SERVICES IN KHULNA CITY IN BANGLADESH

their personal experiences. When anyone asks for suggestions in Foodies Group about the product people convey their attitude by commenting and giving suggestions to them. When people post on review on foodies' group, they give a score the product within 10 marks parameter. This rating helps people to know the perception of people towards the product. When people see a post, they mention their friends and family to the post. So, the others people get to know about the product. Social media enables this type of activity which helps to increase customer engagement. Humaira's pastry, Cake n Bake and Cook Studio sometimes tag their satisfied customer in their promotional post. So, the customer expresses their experience regarding the product and it creates buzz among the target customer.

\section{Discussion}

The rise of social media and its esteem among consumers may be one of the most significant changes in recent years in the area of internet marketing and branding. As proven by the value of online brand involvement on social networking websites, social media have opened up new avenues of communication for companies. Entrepreneurs and brand managers may collaborate with consumers on social networking sites like Facebook, YouTube, and Twitter to increase the exposure of their companies. In this study we find that there are two things that help to develop a brand; firm created communication and user-generated communication. During the survey, it has been clear that the homemade food industry of Khulna operates the business mainly on social media.

Whenever a company gets decided to become involved in social media, it must develop, execute, as well as monitor specific activities upon that chosen social media. Consumer-to-consumer interaction, product or service announcements, free advice and useful data are all examples of popular trends. Another is a higher level of customer service, which involves holding contests and giving away prizes to get people excited. All of these steps must be coordinated with the company's existing online advertising and marketing efforts in order to maximize their effectiveness. In our study, it seems that the homemade food provider tries to associate their product with an online marketing strategy

Brand recognition and image are significantly dependent on company-created social media marketing, according to the report. Various measures are used by store owners to educate their customers. Moreover, they believe that this action aids them in gaining customers. Company-created information exchange is entirely run and administered by business owners. Due to the importance of a company's message and the importance of trustworthiness, it's imperative that businesses map out their social media content to impact customer attitudes about brands.

All the participants in this research clearly identify the engagement in the communities of their choice of an online brand via active sharing, learning, and ratifying activities that fluctuate in participation. They must do research \& share data with other 
Farzana Akther, Sk. Md. Reazul Kabir, Mst. Naznin Sultana, Imtiaz Masroor

EXPLORING THE BRAND BUILDING PROCESS IN MICRO VENTURES THROUGH

SOCIAL MEDIA USAGE: A STUDY OF THE WOMEN-OWNED HOME-BASED COOKED

FOOD DELIVERY SERVICES IN KHULNA CITY IN BANGLADESH

participants and with the brand respectively. As a result of logo-related variables including brand recognition, pride, and faith in the brand, donors are more likely to participate in the project.

One of the explanations why a few social media campaigns now do not work is due to the fact executives aren't seem to be completely dedicated to devoting their thoughts and time to being enthusiastically involved in their marketing through the social media platform. Homemade food providers of Khulna city are mostly women and they have little knowledge about this. It may suggest that firms ought to no longer only be concerned with the online network, also with the offline network to outspread their patron's devotion. Invitations to join the social media community should be sent to the customers. In the online community, corporations need to begin writing greater powerful content. Humble, honest, and concise are the key characteristics of effective content. Information should be there to satisfy the customers who want statistics. While working offline managers/executives should volunteer their service for the development of the relationship with the community. If the executive wants to establish a long-term relationship with the customers timing is a crucial factor. The response to any messages, comments, and posts should be within a day to establish brand equity and expansion of influence. It will also decorate the firm with a knowledge-sharing environment and strengthen relationships between customers and the company.

Social networks created through brand engagement increases customer satisfaction. As part of such interactions, consumers look for comments and previous evaluations from customers who have actually used or sold a service or product. This validates the concept of social benefits. An additional feedback channel that allows people to assess the firm's handling of criticism is provided by certain consumers who post their grievances publicly. Homemade cuisine depends heavily on this.

Consumer attitudes about a brand are influenced by the firm's content, even when this material no longer seems to have a direct impact on customer views of the brand. In addition, a company's social media content may help promote real advertising and marketing to a wider audience by generating a viral reaction. For this reason, the ideal situation for the managers who communicate should encourage customers to generate creative content supporting the brand. It achieves awareness among users because the contents created by the users give a strong message about the brand and business to the users.

\section{Conclusion}

To summarize, organizations must acknowledge the desire to participate in social media and cautiously develop a vibrant approach for doing so. Organizations may listen to their customers, connect with them, and even influence their discussions via the use of social media. Social community platforms provided by the companies gather like-minded customers under the same roof and provide them with the scope to converse into brandrelated issues. Because of this, social media should be considered by the organizations as 
Farzana Akther, Sk. Md. Reazul Kabir, Mst. Naznin Sultana, Imtiaz Masroor

EXPLORING THE BRAND BUILDING PROCESS IN MICRO VENTURES THROUGH

SOCIAL MEDIA USAGE: A STUDY OF THE WOMEN-OWNED HOME-BASED COOKED

FOOD DELIVERY SERVICES IN KHULNA CITY IN BANGLADESH

a key factor to their advertising conversation mix and use it for their communications through advertising in order to expand brand equity. Consumers' increased usage of social media is seemed to own a noteworthy impact on brand fairness in the future. It is advantageous for marketers of using social media in a strategic method because it is a cheap investment that costs less compared to conventional marketing communication methods.

While conducting this research, the following limitations occurred. The most difficult job was to conduct and manage the respondent's because often they didn't feel comfortable giving their opinions towards the questions. At the time of collecting data, sometimes the respondents hadn't enough time and interest to cooperate with the researcher. A non-probability convenient sampling method was used which may not be representative of the total population. There has been difficulty in conducting interviews with the respondents. It is hoped that these difficulties will lead to comprehensive research on how brands should be handled in light of today's social media landscape. On the other hand, social media has the potential of being an effective tool for brands since it gives the organization a platform from which to be heard. Their growing user bases allow consumers to communicate and get access to companies, especially for those who use Facebook as their "primary" site. It is possible for organizations to provide external audiences with the same feeling of belonging that they enjoy amongst themselves, making it easier for them to accept and support the dissemination of their brand's values when the appropriate individual is in charge of employing this technology. They may be able to save money by using the same message for both internal and external audiences. For their part, customers are encouraged to weigh in on the brand's overall strategy by leaving thoughtful feedback. They allow fans to influence the questions of organizations behind the scenes, increasing the relevancy and attraction of their brands. It is possible for Khulna's home-cooked food vendors to benefit from the city's burgeoning social media presence.

\section{Acknowledgements}

Data used in this paper were collected in the process of writing an MBA Thesis in Khulna University by the 2nd author. Authors duly acknowledge the volunteering assistance of Mr. Nafis Sadat Taki, a Senior of the Bachelor of Business Administration Program in Khulna University, who assisted in proofreading certain parts of the paper and editing the diagrams.

\section{Conflict of Interest Statement}

There are no conflicts of interest from the part of the authors.

\section{About the Authors}

Mrs. Farzana Akther is working as an Assistant Professor and Head of the Department of Business Administration at North Western University, Khulna. Mrs. Akther completed her graduation from Khulna University, Khulna, Bangladesh and received MBA in 
Farzana Akther, Sk. Md. Reazul Kabir, Mst. Naznin Sultana, Imtiaz Masroor EXPLORING THE BRAND BUILDING PROCESS IN MICRO VENTURES THROUGH SOCIAL MEDIA USAGE: A STUDY OF THE WOMEN-OWNED HOME-BASED COOKED FOOD DELIVERY SERVICES IN KHULNA CITY IN BANGLADESH

Entrepreneurship Development from Leipzig University in Germany. Her research interest includes internationalization of business, institutional frameworks, innovative marketing approaches and many more.

Mr. Sk. Md. Reazul Kabir is a business graduate having interest in Branding and Promotion. He is looking forward to using his potential and skills in different areas of branding. He has studied MBA majoring in Marketing under Business Administration Discipline in Khulna University, Khulna Bangladesh.

Mrs. Mst Naznin Sultana has completed her graduation majoring in marketing from Khulna University, Khulna, Bangladesh and now her Master degree majoring in Finance is ongoing from Khulna University, Khulna, Bangladesh. She has research interest in customers' purchase intention, pro-environmental purchase decision, volatility in stock price movement and many more.

Mr. Imtiaz Masroor is working as a Lecturer at the Department of Business Administration in North Western University, Khulna, Bangladesh. He has completed his graduation and post-graduation majoring in Finance from Khulna University, Khulna, Bangladesh. He received President Gold Medal, Prime Minister Gold Medal and Dean's Award for securing outstanding result in both BBA and MBA. He has diverse research interest in SME internationalization, firm performance, institutional theories and settings and many more.

\section{References}

Aaker, P. (2000). The Brand Relationship Spectrum: The Key to the Brand Architecture Challenge Volume: 42 Issue: 4, page(s): 8-23

Aaker, D. A. (1991). Managing brand equity. New York: Free Press.

Aaker, D. A. (1996). Building strong brand. New York: Free Press.

Aaker, J. L. (1997). Dimensions of brand personality; Journal of Marketing Research, 34(3), 347-56.

Abhinita Daiya, Subhadip Roy (2016). User and Firm Generated Content on Online Social Media: A Review and Research Directions, International Journal of Online Marketing (IJOM) 6(3).

Ajzen, I. (1991). The theory of planned behavior. Organizational behavior and human decision processes, 50(2), pp.179-211.

Akar, E. and Topçu, B. (2011). An examination of the factors influencing consumers' attitudes toward social media marketing. Journal of internet commerce, 10(1), pp.35-67.

Albert M. Muñiz, Jr., Hope Jensen Schau (2005). Religiosity in the Abandoned Apple Newton Brand Community, Journal of Consumer Research, Volume 31, Issue 4, March, Pages 737-747 
Farzana Akther, Sk. Md. Reazul Kabir, Mst. Naznin Sultana, Imtiaz Masroor

EXPLORING THE BRAND BUILDING PROCESS IN MICRO VENTURES THROUGH

SOCIAL MEDIA USAGE: A STUDY OF THE WOMEN-OWNED HOME-BASED COOKED

FOOD DELIVERY SERVICES IN KHULNA CITY IN BANGLADESH

Andéhn, M., Kazeminia, A., Lucarelli (May 2014). User-generated place brand equity on Twitter: The dynamics of brand associations in social media, Volume 10, Issue 2, pp 132-144

Anderson, R. E. and Srinivasan, S. S. (2003). E-satisfaction and e-loyalty: A contingency framework. Psychology \& Marketing, 20(2), pp.123-138.

Andreas M. Kaplan Michael Haenlei (January-February 2010). Users of the world, unite! The challenges and opportunities of Social Media, Business Horizons, Volume 53, Issue 1, Pages 59-68

Andrew Lipsman, Graham Mudd, Mike Rich, Sean Bruich (1 March 2012). The Power of “Like" How Brands Reach (and Influence) Fans Through Social-Media Marketing, Journal of advertising research, vol. 52 no. $140-52$

Andrew N. Smith, Eileen Fischer, Chen Yongjia (30 March 2012). How Does Brandrelated User-generated Content Differ across YouTube, Facebook, and Twitter? Journal of Interactive Marketing, volume 26, issue 2, pages 102-113

Angella J. Kim, Eunju Ko (October 2012). Do social media marketing activities enhance customer equity? An empirical study of luxury fashion brand, Journal of Business Research volume 65, Pages 1480-1486

Arjun Chaudhuri, Morris B. Holbrook (April 1, 2001). The Chain of Effects from Brand Trust and Brand Affect to Brand Performance: The Role of Brand Loyalty journal of marketing Volume: 65 issue: 2, page(s): 81-93

Bearden, W. O. and Etzel, M. J. (1982). Reference group influence on product and brand purchase decisions. Journal of consumer research, 9(2), pp.183-194.

Berthon, P., Ewing, M. T. and Napoli, J. (2008). Brand management in small to mediumsized enterprises. Journal of small business management, 46(1), pp.27-45.

Berthon, P. R., Pitt, L. F., Plangger, K. and Shapiro, D. (2012). Marketing meets Web 2.0, social media, and creative consumers: Implications for international marketing strategy. Business horizons, 55(3), pp.261-271.

Bhattacherjee, A., \& Premkumar, G. (2004). Understanding changes in belief and attitude toward information technology usage: a theoretical model and longitudinal test. MIS Quarterly. 28(2)

Bilal, M., Jianqu, Z. and Ming, J. (2021). How Consumer Brand Engagement Effect on Purchase Intention? The Role of Social Media Elements. Journal of Business Strategy Finance and Management, 2(1).

Blackston, Max (July 1992). A brand with an attitude: a suitable case for treatment, Journal of the Market Research Society, Vol. 34, Issue 3, p. 231

Brodie, R. J., Ilic, A., Juric, B. and Hollebeek, L. (2013). Consumer engagement in a virtual brand community: An exploratory analysis. Journal of business research, 66(1), pp.105-114.

Burgess, J. and Banks, J. (2010). User-created content and online social networks. The Media and Communications in Australia (3rd Edition), pp.295-306.

Burmann, C., Schaefer, K. and Maloney, P. (2008). Industry image: Its impact on the brand image of potential employees. Journal of brand management, 15(3), pp.157-176. 
Farzana Akther, Sk. Md. Reazul Kabir, Mst. Naznin Sultana, Imtiaz Masroor EXPLORING THE BRAND BUILDING PROCESS IN MICRO VENTURES THROUGH SOCIAL MEDIA USAGE: A STUDY OF THE WOMEN-OWNED HOME-BASED COOKED FOOD DELIVERY SERVICES IN KHULNA CITY IN BANGLADESH

Castillo, A., Benitez, J., Llorens, J. and Luo, X. R. (2021). Social media-driven customer engagement and movie performance: Theory and empirical evidence. Decision Support Systems, 145, p.113516.

Catherine Houghton, Kathy Murphy, David Shaw, Dympna Casey (16 April 2014). Qualitative case study data analysis: an example from practice, Nurse Researcher. $22,5,8-12$

Chaudhuri, A. and Holbrook, M. B. (2001). The chain of effects from brand trust and brand affect to brand performance: the role of brand loyalty. Journal of marketing, 65(2), pp.81-93.

Chen, G. M. (2012). The impact of new media on intercultural communication in global context.

Chen, L. and Zhu, F. (2021). Seller information sharing in online marketplaces. Journal of Marketing Management, pp.1-28.

Childers, C. and Boatwright, B. (2021). Do digital natives recognize digital influence? Generational differences and understanding of social media influencers. Journal of Current Issues \& Research in Advertising, 42(4), pp.425-442.

Chris A. Myers (2003). Managing brand equity: a look at the impact of attributes, Journal of Product \& Brand Management, Vol.12 Iss. 1 pp. 39 - 51

Cobb-Walgren, C. and Mohr, L. (1998). Symbols in service advertisements, Journal of Services Marketing, Vol. 12 No. 2, pp. 129-151

Cobb-Walgren, C. J., \& Ruble, C. A. (1995). Brand equity, brand preference, and purchase intent. Journal of Advertising, 24(3), 25-41

Colin Campbell, Leyland F. Pitt, Michael Parent \& Pierre R. Berthon (2011). Understanding Consumer Conversations Around Ads in a Web 2.0 World, Journal of Advertising, 40:1, 87-102

Correa, T., Hinsley, A. W. and De Zuniga, H. G. (2010). Who interacts on the Web?: The intersection of users' personality and social media use. Computers in human behavior, 26(2), pp.247-253.

Daiya, A. and Roy, S. (2016). User and firm generated content on online social media: A review and research directions. International Journal of Online Marketing (IJOM), 6(3), pp.34-49.

De Bruyn, Arnaud and Gary L. Lilien (2008). A Multi-Stage Model of Word-of Mouth Influence through Viral Marketing, International Journal of Research in Marketing, 25, 3, 151-63.

Delgado-Ballester, E. (2004). Applicability of a brand trust scale across product categories: A multigroup invariance analysis, European Journal of Marketing, Vol. 38 No. 5/6, pp. 573-592.

Delgado-Ballester, E. and Luis Munuera-Alemán, J. (2005). Does brand trust matter to brand equity? Journal of Product \& Brand Management, Vol. 14 No. 3, pp. 187196.

Dickey, Irene J. and Lewis, William F. (2010). The Evolution (Revolution) of Social Media and Social Networking as a Necessary Topic in the Marketing Curriculum: A Case 
Farzana Akther, Sk. Md. Reazul Kabir, Mst. Naznin Sultana, Imtiaz Masroor

EXPLORING THE BRAND BUILDING PROCESS IN MICRO VENTURES THROUGH

SOCIAL MEDIA USAGE: A STUDY OF THE WOMEN-OWNED HOME-BASED COOKED

FOOD DELIVERY SERVICES IN KHULNA CITY IN BANGLADESH

for Integrating Social Media into Marketing Classes, Management and Marketing Faculty Publications. 32

Ellen Garbarino, Mark S. Johnson, (April 1, 1999). The Different Roles of Satisfaction, Trust, and Commitment in Customer Relationships journal of marketing Volume: 63 issue: 2 , page(s): $70-87$

Erfan Severi \& Kwek Choon (2013). The Mediating Effects of Brand Association, Brand Loyalty, Brand Image and Perceived Quality on Brand Equity; Asian Social Science; Vol. 9, No. 3;

Erkan Akar \& Birol Topçu (2011). An Examination of the Factors Influencing Consumers' Attitudes Toward Social Media Marketing, Journal of Internet Commerce, 10:1, 35 67

Gaini, R. R., Patel, K. M., Khan, S. A., Singh, N. P. and Love, M. N. (2021). A rise in social media utilization by US neurology residency programs in the era of COVID19. Clinical Neurology and Neurosurgery, p.106717.

Gallaugher, J., \& Ransbotham, S. (2010). Social media and customer dialog management at Starbucks. MIS Quarterly Executive, 9(4), 197-212.

Gashi, R. and Ahmeti, H. (2021). Impact of Social Media on the Development of New Products, Marketing and Customer Relationship Management in Kosovo. Emerging Science Journal, 5(2), pp.125-138.

Gensler, S., Völckner, F., Liu-Thompkins, Y. and Wiertz, C. (2013). Managing brands in the social media environment. Journal of interactive marketing, 27(4), pp.242-256.

Gordon Fullerton, (08 April 2009). The Impact of Brand Commitment on Loyalty to Retail Service Brands, Canadian journal of administrative science, Volume22, Issue2, Pages 97-110

Gruen, T. W., Osmonbekov, T. D. \& Czaplewski, A. J. (2006). eWOM: The impact of customer-to-customer online know-how exchange on customer value and loyalty, Journal of Business Research, vol. 59, no. 4, pp. 449-456

Harmila C. Chatterjee, Arjun Chaudhuri (2005). Are Trusted Brands Important? The Marketing Management Journal Volume 15, Issue 1, Pages 1 - 16

Hawkins, Kerrie; Vel, Prakash (Summer 2013). Attitudinal loyalty, behavioural loyalty and social media: An introspection The Marketing Review, Volume 13, Number 2, pp. 125-141(17)

Hazzam, J. (2021). The moderating role of age on social media marketing activities and customer brand engagement on Instagram social network. Young Consumers.

Houghton, C., Murphy, K., Shaw, D. and Casey, D. (2015). Qualitative case study data analysis: An example from practice. Nurse researcher, 22(5).

Hsieh, A. and Li, C. (2008). The moderating effect of brand image on public relations perception and customer loyalty, Marketing Intelligence \& Planning, Vol. 26 No. 1 , pp. 26-42.

Hu-Chuan Chu \& Yoojung Kim (2011). Determinants of consumer engagement in electronic word-of-mouth (eWOM) in social networking sites, International Journal of Advertising, 30:1, 47-75 
Farzana Akther, Sk. Md. Reazul Kabir, Mst. Naznin Sultana, Imtiaz Masroor EXPLORING THE BRAND BUILDING PROCESS IN MICRO VENTURES THROUGH SOCIAL MEDIA USAGE: A STUDY OF THE WOMEN-OWNED HOME-BASED COOKED FOOD DELIVERY SERVICES IN KHULNA CITY IN BANGLADESH

Hutter, K., Hautz, J., Dennhardt, S. and Füller, J. (2013). The impact of user interactions in social media on brand awareness and purchase intention: the case of MINI on Facebook, Journal of Product \& Brand Management, Vol. 22 No. 5/6, pp. 342-351

Hyuk Jun Cheong \& Margaret A. Morrison (2008). Consumers' Reliance on Product Information and Recommendations Found in UGC, Journal of Interactive Advertising, 8:2, 38-49

I. Ajzen, (1991). The theory of planned behavior, Organizational Behavior and Human Decision Processes 179-211

Ishfaq Rahim Khanday, Syed Mafid Rashid Andrabi, (March-2018). Impact of Online Reviews and Ratings on Buying Behavior, International Journal of Enhanced Research in Management \& Computer Applications, Volume 7

Jacoby, J. (1971). Brand loyalty: A conceptual definition, Proceedings of the Annual Convention of the American Psychological Association, 6(Pt. 2), 655-656.

James H. McAlexander, John W. Schouten, Harold F. Koenig (January 1, 2002). Building Brand Community, Journal of marketing, Volume: 66 issue: 1, page(s): 38-54

Jo Brown, Amanda J. Broderick, Nick Lee, (09 August 2007). Word of mouth communication within online communities: Conceptualizing the online social network, Journal of Interactive Marketing, Volume2, Pages 2-20

John W. Schouten, James H. McAlexander (1995). Subcultures of Consumption: An Ethnography of the New Bikers, Journal of Consumer Research, Volume 22, Issue 1, June, Pages 43-61.

Jonah Berger, Katherine L. Milkman, (April 1, 2012). What Makes Online Content Viral? Journal of marketing research, Volume: 49 issue: 2, page(s): 192-205

Josh Bernoff and Charlene Li (Spring, 2008). Harnessing the Power of the Oh-So-Social Web MIT Solan Management Review, vol.49 no 3

Kaplan, A. M. and Haenlein, M. (2010). Users of the world, unite! The challenges and opportunities of Social Media. Business horizons, 53(1), pp.59-68.

Karakaya, F. and Ganim Barnes, N. (2010). Impact of online reviews of customer care experience on brand or company selection, Journal of Consumer Marketing, Vol. 27 No. 5, pp. 447-457

Keller, K. L. (1993). Conceptualizing, measuring, managing customer-based brand equity, Journal of Marketing, Vol. 57 No. 1, pp. 1-22

Keller, K. L. (1998). Branding perspectives on social marketing. ACR North American Advances.

Kevin Lane Keller (1998). Branding Perspectives on Social Marketing, in NA - Advances in Consumer Research Volume 25, eds. Joseph W. Alba \& J. Wesley Hutchinson, Provo, UT: Association for Consumer Research, Pages: 299-302

Kim Bartel Sheehan \& Deborah K. Morrison (2009). The Creativity Challenge, Journal of Interactive Advertising, 9:2, 40-43

Kim, A. J. and Ko, E. (2012). Do social media marketing activities enhance customer equity? An empirical study of luxury fashion brand. Journal of Business research, 65(10), pp.1480-1486. 
Farzana Akther, Sk. Md. Reazul Kabir, Mst. Naznin Sultana, Imtiaz Masroor EXPLORING THE BRAND BUILDING PROCESS IN MICRO VENTURES THROUGH SOCIAL MEDIA USAGE: A STUDY OF THE WOMEN-OWNED HOME-BASED COOKED FOOD DELIVERY SERVICES IN KHULNA CITY IN BANGLADESH

Korkofingas, C. and Ang, L. (2010). Spill-over: The effects of product recall on private labels versus national brands. In Australian and New Zealand Marketing Academy (ANZMAC) Conference. Accessed: October (Vol. 30, p. 2010).

Kwayu, S., Abubakre, M. and Lal, B. (2021). The influence of informal social media practices on knowledge sharing and work processes within organizations. International Journal of Information Management, 58, p.102280.

Laroche, M., Habibi, M. R. and Richard, M. O. (2013). To be or not to be in social media: How brand loyalty is affected by social media?. International journal of information management, 33(1), pp.76-82.

Lashgari, M., Sutton-Brady, C., Søilen, K. S. and Ulfvengren, P. (2018). Adoption strategies of social media in B2B firms: a multiple case study approach. Journal of Business \& Industrial Marketing.

Lau, G. T., Lee, S. H. (1999). Consumers' Trust in a Brand and the Link to Brand Loyalty. Journal of Market-Focused Management 4, 341-370).

Laurence Dessart, Cleopatra Veloutsou, Anna Morgan-Thomas (2015). Consumer engagement in online brand communities: a social media perspective, Journal of Product \& Brand Management, Vol. 24 Issue: 1, pp.28-42

Leckie, C., Nyadzayo, M. W. and Johnson, L. W. (2016). Antecedents of consumer brand engagement and brand loyalty. Journal of Marketing Management, 32(5-6), pp.558-578.

Li, C., Bernoff, J. and Groot, M. (2011). Groundswell. Thema.

Lipsman, A., Mudd, G., Rich, M. and Bruich, S. (2012). The power of "like": How brands reach (and influence) fans through social-media marketing. Journal of Advertising research, 52(1), pp.40-52.

Mangold, W. G. and Faulds, D. J. (2009). Social media: The new hybrid element of the promotion mix. Business horizons, 52(4), pp.357-365.

Munting, D. G., Moorman, M., \& Smit, E. G. (2011). Introducing COBRAs: Exploring motivations for brand-related social media use. International Journal of Advertising, 30(1), 13-46

Nima Heirati, Aron O'Cass \& Liem Viet Ngo (2013). The contingent value of marketing and social networking capabilities in firm performance, Journal of Strategic Marketing,21:1, 82-98

Norman Booth, Julie Ann Matic (2011). Mapping and leveraging influencers in social media to shape corporate brand perceptions, Corporate Communications: An International Journal, Vol. 16 Issue: 3, pp. 184-191

Park, C. S. and Srinivasan, V. (1994). A survey-based method for measuring and understanding brand equity and its extendibility. Journal of marketing research, 31(2), pp.271-288.

Piaralal, S. and Mei, T. M. (2015). Determinants of brand equity in private healthcare facilities in Klang Valley, Malaysia. American Journal of Economics, 5(2), pp.177182. 
Farzana Akther, Sk. Md. Reazul Kabir, Mst. Naznin Sultana, Imtiaz Masroor

EXPLORING THE BRAND BUILDING PROCESS IN MICRO VENTURES THROUGH

SOCIAL MEDIA USAGE: A STUDY OF THE WOMEN-OWNED HOME-BASED COOKED

FOOD DELIVERY SERVICES IN KHULNA CITY IN BANGLADESH

Pierre R. Berthon Leyland F. Pitt Kirk Plangger Daniel Shapiro (May-June 2012). Marketing meets Web 2.0, social media, and creative consumers: Implications for international marketing strategy Business Horizons Volume 55, Issue 3, Pages 261271

Pitta, D. A. and Katsanis, L. P. (1995). Understanding brand equity for successful brand extension. Journal of consumer marketing.

Portal, S., Abratt, R. and Bendixen, M. (2019). The role of brand authenticity in developing brand trust. Journal of Strategic Marketing, 27(8), pp.714-729.

Raji, R. A., Mohd Rashid, S., Mohd Ishak, S. and Mohamad, B. (2020). Do firm-created contents on social media enhance brand equity and consumer response among consumers of automotive brands?. Journal of Promotion Management, 26(1), pp.19-49.

Richardson, P. S., Dick, A. S. and Jain, A. K. (1994). Extrinsic and intrinsic cue effects on perceptions of store brand quality. Journal of marketing, 58(4), pp.28-36.

Ringberg, T. and Forquer Gupta, S. (2003). The importance of understanding the symbolic world of customers in asymmetric business-to-business relationships, Journal of Business \& Industrial Marketing, Vol. 18 No. 6/7, pp. 607-626.

Robert V. Kozinets, Kristine De Valck, Andrea C. Wojnicki, Sarah J. S. Wilner, (March 1, 2010). Networked Narratives: Understanding Word-of-Mouth Marketing in Online Communities, journal of marketing, Volume: 74 issue: 2, page(s): 71-89

Rolph E. Anderson, Srini S. Srinivasan (17 January 2003). E-satisfaction and e-loyalty: A contingency framework Volume 20, Issue2 Pages 123-138.

Rosemary Thackeray, Brad L. Neiger, Carl L. Hanson, James F. McKenzie, (March 19, 2008). Enhancing Promotional Strategies within Social Marketing Programs: Use of Web 2.0 Social Media, Volume: 9 issue: 4, page(s): 338-343

Roy, D. and Banerjee, S. (2007). CARE-ing strategy for integration of brand identity with brand image. International journal of commerce and management.

Ruth M. W. Yeung, Joe Morris (2001). Food safety risk: Consumer perception and purchase behavior, British Food Journal, Vol. 103 Issue: 3, pp.170-187

Saini, A. and Chauhan, S. (2017). Impact of celebrity endorsement on brands and brand equity: A review contribution to brand literature. Journal of commerce, economics \& computer science, 3(4), pp.131-135.

Sashi, C. (2012). Customer engagement, buyer-seller relationships, and social media, Management Decision, Vol. 50 No. 2, pp. 253-272.

Shearer, E. and Mitchell, A. (2021). News use across social media platforms in 2020.

Silke Bambauer-Sachse and Sabrina Mangold (2011). The Role of Perceived Review Credibility in the Context of Brand Equity Dilution Through Negative Product Reviews on the Internet, in NA - Advances in Consumer Research Volume 38

Silke Bambauer-Sachse, Sabrina Mangold (January 2011). Brand equity dilution through negative online word-of-mouth communication, Journal of retailing and consumer service, Volume 18, Issue 1, Pages 38-45 
Farzana Akther, Sk. Md. Reazul Kabir, Mst. Naznin Sultana, Imtiaz Masroor EXPLORING THE BRAND BUILDING PROCESS IN MICRO VENTURES THROUGH SOCIAL MEDIA USAGE: A STUDY OF THE WOMEN-OWNED HOME-BASED COOKED FOOD DELIVERY SERVICES IN KHULNA CITY IN BANGLADESH

Sonja Gensler Franziska Völckner Yuping Liu-Thompkins Caroline Wiertz (30 October 2013). Managing Brands in the Social Media Environment, Journal of interactive marketing Volume 27, Issue 4 Pages 242-256

Swain, A. and Cao, Q. (2014 January). Impact of online firm generated content (FGC) on supply chain performance: An empirical analysis. In 2014 47th Hawaii International conference on system sciences (pp. 561-573). IEEE.

Tajvidi, R. and Karami, A. (2021). The effect of social media on firm performance. Computers in Human Behavior, 115, p.105174.

Teres Correa, Amber Willard Hinsley, Homero Gilde Zúñiga (25 October 2009). Who interacts on the Web?: The intersection of users' personality and social media use, Computers in Human Behavior, Volume 26, Issue 2, Pages 247-253

Terry Daugherty, Matthew S. Eastin \& Laura Bright (2008). Exploring Consumer Motivations for Creating User-Generated Content, Journal of Interactive Advertising, 8:2, 16-25

Thackeray, R., Neiger, B. L., Hanson, C. L. and McKenzie, J. F. (2008). Enhancing promotional strategies within social marketing programs: use of Web 2.0 social media. Health promotion practice, 9(4), pp.338-343.

Timothy Cawsey Jennifer Rowley (2016). Social media brand building strategies in B2B companies, Marketing Intelligence \& Planning, Vol. 34

W. Glynn Mangold David J. Fauld (10 April 2009). Social media: The new hybrid element of the promotion mix, Business Horizon, Volume 52, Issue 4, Pages 357-365

William O. Bearden, Michael J. Etzel (1982). Reference Group Influence on Product and Brand Purchase Decisions Journal of Consumer Research, Volume 9, Issue 2, September, Pages 183-194

Willmott, M. J. Brand Manag (2003). Citizen brands: Corporate citizenship, trust and branding, Journal of Brand Management, Volume 10, Issue 4, pp 362-369. 
Farzana Akther, Sk. Md. Reazul Kabir, Mst. Naznin Sultana, Imtiaz Masroor

Creative Commons licensing terms

Authors will retain copyright to their published articles agreeing that a Creative Commons Attribution 4.0 International License (CC BY 4.0) terms will be applied to their work. Under the terms of this license, no permission is required from the author(s) or publisher for members of the community to copy, distribute, transmit or adapt the article content, providing a proper, prominent and unambiquous attribution to the authors in a manner that makes clear that the materials are being reused under permission of a Creative Commons License. Views, opinions and conclusions expressed in this research article are views, opinions and conclusions of the author(s). Open Access Publishing Group and European Journal of Management and Marketing Studies shall not be responsible or answerable for any loss, damage or liability caused in relation to/arising out of conflict of interests, copyright violations and inappropriate or inaccurate use of any kind content related or integrated on the research work. All the published works are meeting the Open Access Publishing requirements and can be freely accessed, shared, modified, distributed and used in educational, commercial and non-commercial purposes under a Creative Commons Attribution 4.0 International License (CC BY 4.0). 